\title{
11ß-Hydroxylation of cortexolone (Reichstein's compound S) to hydrocortisone using immobilized Cunninghamella elegans spores
}

\author{
Allam, R. F. ${ }^{1}$, Shafei, M. S. ${ }^{1 \star}$, Refai A. H. El. ${ }^{1}$, Ali, M. I. ${ }^{2}$ and Mohamed, S. S. ${ }^{1}$ \\ ${ }^{1}$ Chemistry of Natural and Microbial Products, National Research Center, Cairo. Egypt. \\ ${ }^{2}$ Faculty of Science, Cairo University, Cairo. Egypt. \\ E-mail: mona_sayed@hotmail.com
}

Received 8 November 2009; received in revised form 15 March 2010; accepted 29 April 2010

\begin{abstract}
Two steps bioconversion of cortexolone (Reichstein's compound $S$ ) to its $\Delta^{1}$-dehydro- $11 \beta$-hydroxy derivatives and prednisolone, was successfully performed by the use of $C$. elegans for the production of cortisol and prednisolone from cortexolone. The combinations of sequential reactions, $11 \beta$-hydroxylation and $\Delta^{1}$-dehydrogenation were performed by immobilized spores of Cunninghamella elegans. The immobilization technique was carried by either entrapment in sodium alginate or by adsorption on silver, 8 micron glass wool method. Maximum production of cortisol and prednisolone were obtained after $72 \mathrm{~h}$ transformation period using immobilized spores of $C$. elegans of concentration $2 \mathrm{x}$ $10^{7}$ spores $/ \mathrm{mL}$ for both entrapment and adsorption. The highest transformation efficiency was recorded on using $1.6 \%$ $\mathrm{w} / \mathrm{v}$ glass wool (92\%) compared to that when the fungal spores were entrapped in $3 \%$ alginate (84\%). Each immobilized microbial system was stable and could be used for the sequential reactions repeatedly (operational period, 18 days using entrapped $C$. elegans in alginate beads and 45 days using adsorbed spores on glass wool).
\end{abstract}

Keywords: hydroxylation, immobilization, cortexolone, cortisol, prednisolone

\section{INTRODUCTION}

The importance of microbial biotechnology in the production of steroid drugs and hormones was realized for the first time in 1952 when Peterson and Murray (1952) patented the process of $11 \alpha$-hydroxylation of progesterone by a Rhizopus species. Since then, microbial reactions for the transformation of steroids have proliferated and specific microbial transformation steps have been incorporated into numerous partial synthesis of new steroids for the evaluation as drugs and hormones. These biotransformation have provided adequate tools for the large scale production of natural or modified steroid analogues (Asha and Vidyavathi, 2009).

Hydroxylations are possibly the most wide spread type of steroid bioconversions. Hydroxylations can be used to build intermediates for further chemical synthesis, by offering access to otherwise inaccessible sites of the steroid molecule, or to provide the steroid molecule with the adequate structure for therapeutic applications (Fernandes et al., 2003). 11 $\beta$-Hydroxylation of steroids is an important reaction to produce hydrocortisone $(11 \beta, 17 \alpha$, 21-trihydroxypregn-4-ene-3, 20dione, cortisol or substance $F$ of Kendal) which is a principal pharmaceutical and also the precursor of the potent steroid like prednisolone (Naim et al., 2003; Lu et al., 2007). The 11 $\beta$-hydroxylation of cortexolone by fung belongs to transformation of biotechnological importance. It is a direct way to obtain cortisol, a pharmaceutical corticosteroid of considerable commercial value
(Schmauder et al., 1991; Mahato and Garai, 1997; Sripalakit et al., 2006). Fungal steroid 11 $\beta$-hydroxylation was catalyzed by cytochrome P450 monooxygenases (Suzuki et al., 1993; Paraszkiewiez and Dlugonski 1998). Cytochrome P450 is responsible for the oxygen insertion in the steroid substrate molecule (Lu et al., 2006).

Increasing interests and endeavours have been focused on the application of immobilized microbial cells for conducting biotransformations to produce useful compounds e.g 11ß-hydroxylation of cortexolone by entrapment living mycelia of Curvutaria lunata (Sonomoto et al., 1981).

The protective microenvironment provided by the immobilized cells represents a major advantage, particularly when separate organic phase is present (Dias et al., 1994; Houng et al .,1994). Mass transfer limitation due to inadequate partition of the lipophilic substrates into hydrophilic gels have been reduced through the use of polyurea-coated alginate beads (Fernandes et al., 2003). Thus immobilized cell cultures may be efficient biocatalysts than free cells (Koshcheyenko et al., 1983). However, mycelial cells of fungi are fragile, and complex hydroxylation systems are liable to lose their activity.

The most obvious benefit of the immobilization technique is the capability of continuous cycling which provides a mean for using them in continuous cultures maintaining high cell population to achieve fast reaction rates (Koshcheyenko et al., 1983). 
The objective of the present study was to adopt two kinds of immobilization techniques (entrapping in calcium alginate gel and adsorption on glass wool) using Cunninghamelta elegans spores. The effect of some factors affecting the $11 \beta$-hydroxylation process such as sodium-alginate and glass wool concentrations, number of spores entrapped in the gel and that adsorbed on glass wool, the optimum bioconversion time for both and also the repeated use of the immobilized spores were also studied.

\section{MATERIALS AND METHODS}

\section{Microorganism}

Cunninghamella elegans RCMB 012001 was kindly obtained from the regional center of fungi, Al-Azhar University, Egypt.

\section{Chemicals}

Reichstein's compound S (cortexolone; 17 $\alpha, 21$-dihydroxypregn-4-ene-3,20-dione) was the substrate, cortisol (hydrocortisone; Kendal's compound F; 11 $\beta, 17 \alpha, 21$ trihydroxy-4-pregnene-3,20-dione) and prednisolone (11 $\beta, 17 \alpha, 21$-trihydroxy-1,4-pregnadiene-3,20-dione) were the standards for the $11 \beta$-hydroxylation and $\Delta^{1-2}$. dehydrogenation products and were provided by Sigma Company, U.S.A. Sodium alginate was a product of panreac Quimica (Espania). Glass wool was pyrex fiber glass, silver 8 micron coring glass work, Coring (U.S.A).

\section{Preparation of immobilized spores in alginate beads}

Sodium alginate solution $3 \%$ was prepared by dissolving $0.3 \mathrm{~g}$ in $7 \mathrm{~mL}$ distilled water. The resulting gel was autoclaved at $120{ }^{\circ} \mathrm{C}$ for $10 \mathrm{~min}$ then $3 \mathrm{~mL}$ of the fungal spores were added to the sterile alginate solution to obtain $3 \%$ final concentration. The previously prepared alginatespores mixture was dripped into stirred $2 \% \mathrm{CaCl}_{2}$ solution $(\mathrm{w} / \mathrm{v})$. The alginate beads were cured by stirring in $\mathrm{CaCl}_{2}$ for further $2 \mathrm{~h}$ at room temperature and then transferred to the refrigerator at $5{ }^{\circ} \mathrm{C}$ overnight in order to increase their stability.

The beads were then collected and washed thoroughly using sterile $0.5 \% \mathrm{NaCl}$ solution $(\mathrm{w} / \mathrm{v})$ and then transferred to $50 \mathrm{~mL}$ fermentation medium (Fraser and Bickerstaff, 1997). The reaction was induced by adding 0.5 $\mathrm{mg}$ substrate for $8 \mathrm{~h}$ and then $5 \mathrm{mg}$ of the steroid substrate was added and incubated for $48 \mathrm{~h}$ at $30^{\circ} \mathrm{C}$ on a rotary shaker (120 rpm).

\section{Preparation of immobilized spores adsorbed on glass wool}

Immobilization of Cunninghamella elegans spores on glass wool was performed. Glass wool $(0.8 \mathrm{~g})$ was added to $50 \mathrm{~mL}$ of the fermentation medium unless otherwise stated. After sterilization, the flasks were left for $24 \mathrm{~h}$ on a shaking incubator at $200 \mathrm{rpm}$ to form a thin, circular pad of glass wool network. Each flask was inoculated with $3 \mathrm{~mL}$ spore suspension and the biotransformation process was carried out as it will be subsequently mentioned. For repeated batch biotransformation, the fermentation medium was decanted at the end of each cycle and the glass wool pads were carefully squeezed and washed with $0.5 \% \mathrm{NaCl}(\mathrm{w} / \mathrm{v})$. The glass wool pads were then aspectically transferred to freshly prepared sterilized medium (Farid et al., 1994).

\section{Steroid transformation by immobilized spores}

The immobilized spores of $C$. elegans (either using alginate beads or glass wool) were transferred to $50 \mathrm{~mL}$ of the fermentation medium $(\mathrm{g} / \mathrm{L})$ : yeast extract, 5 ; bacto peptone, 5; glucose, 20; $\mathrm{NaCl}, 5 ; \mathrm{K}_{2} \mathrm{HPO}_{4}, 5 ; \mathrm{pH}$ 6.0. The substrate $(0.5 \mathrm{mg})$ was added as an inducer for $8 \mathrm{~h}$ followed by the addition of substrate to each flask (5 $\mathrm{mg} / 50 \mathrm{~mL}$ ) and incubated for $48 \mathrm{~h}$ at $30{ }^{\circ} \mathrm{C}$ on a rotary shaker (120 rpm) (Chinckolkar et al., 1995).

\section{Extraction, qualitative and quantitative analysis of steroid compounds}

The filtrates (collected after each transformation run) were extracted with chloroform $(100 \mathrm{~mL})$. The steroid substances present in the tested materials were estimated by thin layer chromatography with Kieselgel 60G. The amount of products were estimated by LC Module HPLC with software (Millenium 2010). The mobile phase used was $50 \%$ methanol and $5 \%$ water, $\mathrm{mL} / \mathrm{min}$ with $\mathrm{C}-18$ Novopak Column and U.V. detector (SPD- 10AVP/ 154 $\mathrm{nm}$ ) (Houng et al., 1994).

\section{RESULTS AND DISCUSSION}

\section{Effect of different concentrations of sodium alginate on cortexolone bioconversion to cortisol and prednisolone}

Immobilization of fungal spores in gel matrices with subsequent germination and development into mycelia network overcomes the problems associated with the immobilization preformed by vegetative mycelia (Sonomoto et al., 1983). The rigidity and size of the gel concentration seems to be critical for spore germination. In fact, the size of gel concentration markedly affected the growth and $11 \beta$ - hydroxylation. Thus the gel concentration is an important factor for steroid $11 \beta$-hydroxylation activity.

The $C$. elegans spores were entrapped in sodium alginate at different concentrations $(1 \%, 2 \%, 3 \%, 4 \%, 5 \%)$. Table 1 indicates that the $11 \beta$-hydroxylation capacity of the immobilized spores of $C$. elegans depended on the concentration of the entrapping agent. A $3 \%$ of sodium alginate proved to be the most suitable concentration for cortexolone bioconversion. Thus, the bioconversion capacities exhibited 1.2 folds increase as compared with the control (free spores). 
Table 1: Effect of alginate concentrations on $11 \beta$-hydroxylation of cortexolone using entrapped spores of $C$. elegans

\begin{tabular}{|c|c|c|c|c|c|}
\hline \multirow{2}{*}{$\begin{array}{c}\text { Na-alginate } \\
\text { concentration (\%) }\end{array}$} & \multicolumn{5}{|c|}{ Transformation mixture (mg/50mL medium) } \\
\hline & Cortisol & Prednisolone & $\begin{array}{c}20 \beta \text {-hydroxy } \\
\text { cortisol }\end{array}$ & $\begin{array}{c}\text { Residual } \\
\text { cortexolone }\end{array}$ & $\begin{array}{c}\text { Transformation } \\
\text { Efficiency (\%) }\end{array}$ \\
\hline 1 & 1.3 & 1.2 & 0.8 & 1.4 & 52 \\
\hline 2 & 1.6 & 1.5 & 0.9 & 0.8 & 61 \\
\hline 3 & 1.8 & 1.6 & 1.0 & 0.4 & 68 \\
\hline 4 & 1.7 & 1.6 & 0.7 & 0.7 & 61 \\
\hline 5 & 1.6 & 1.5 & 0.5 & 1.1 & 59 \\
\hline Control $^{*}$ & 1.5 & 1.4 & 0.9 & 0.9 & 59 \\
\hline
\end{tabular}

- Control is the free spores of C.elegans.

- Cortexolone concentration $=5 \mathrm{mg} / 50 \mathrm{~mL}$ medium

Table 2: Effect of different inoculum sizes of entrapped spores of $C$. elegans on the conversion of cortexolone

\begin{tabular}{cccccc}
\hline \multirow{2}{*}{ Inoculum size (\%) } & Cortisol & Prednisolone & $\begin{array}{c}\text { 20 } \beta \text {-hydroxy } \\
\text { cortisol }\end{array}$ & $\begin{array}{c}\text { Residual } \\
\text { cortexolone }\end{array}$ & $\begin{array}{c}\text { Transformation } \\
\text { Efficiency (\%) }\end{array}$ \\
\cline { 2 - 6 } & 1.3 & 1.2 & 0.6 & 1.7 & 50 \\
1.7 & 0.7 & 0.9 & 62 \\
15 & 1.6 & 1.7 & 1.1 & 0.3 & 72 \\
20 & 1.9 & 1.6 & 0.8 & 0.7 & 66 \\
25 & 1.7 & 1.4 & 0.7 & 1.0 & 59 \\
\hline
\end{tabular}

- Cortexolone concentration $=5 \mathrm{mg} / 50 \mathrm{~mL}$ medium

- Sodium alginate concentration $=3 \%$

On the other hand the utilization of sodium alginate concentration more than $3 \%$ affected the transformation process adversely (Fukui et al., 1980). Similar results have been recorded by Wang et al. (1998) and Dlugonski et al. (1997).

\section{Effect of different inoculum sizes of entrapped spores of C. elegans on the conversion of cortexolone}

Different amounts of spore suspension were used $(5,10$, 15,20 and $25 \mathrm{~mL}$ ) to prepare the alginate beads (Table 2) The 11ß-hydroxylation process was affected by the amount of spores. The yields of cortisol and prednisolone increased with the increase of spore number up to 15 $\mathrm{mL} / 50 \mathrm{~mL}$ medium which allowed maximal bioconversion of cortexolone (72\%). On the other hand, higher concentrations of the spore suspensions exerted a deleterious effect on the enzymatic activity of fungal spores. This may be due to the bulky formation of the spores in the formed beads which may inhibit aeration and in turn inhibits the exchange of oxygen, which is an important limiting factor in the hydroxylation process (Martine, 1984; Lu et al., 2006; Manosroi et al., 2006). It is well known that cytochrom P450 acts as the key component in the steroid $11 \beta$-hydroxylation systems, which is responsible for the oxygen insertion into the steroid molecule (Lu et al., 2007). On the other hand, Manosroi et al. (2007) found that $1 \times 10^{3}$ initial cell number was the best concentration to get hydrocortisone acetate from cortexolone-21-acetate using C. blakesleeana ATCC 8688a.

Effect of transformation period on the bioconversion of cortexolone using entrapped $C$. elegans spores

The effect of the bioconversion time course as an effective factor in the 11 $\beta$-hydroxylation of cortexolone using $C$. elegans spores entrapped in $3 \%$ alginate gel was investigated. Table 3 indicates that the best bioconversion estimates were reached after $72 \mathrm{~h}$ which was the optimal transformation period for attaining maximal favourable transformation activities (84\%) using entrapped fungal spores. Increasing the transformation periods more than $72 \mathrm{~h}$ led to a decrease in the $11 \beta$-hydroxylation activity. This may be due to the lysis of beads containing spores and the level of the enzymic activity of the immobilized system can be controlled by changing the intensity of cell propagation within the gel (Lusta et al., 1989). It was previously stated that $63 \mathrm{~h}$ was the best time to get hydrocortisone using Absidia archidis (Wang et al., 1998). On the other hand, Yang et al. (2007) stated that rimexolone was obtained by microbial hydroxylation of I6 $\alpha, 17 \alpha$-dimethyl-17 $\beta$-(1-oxopropyl) androsta-1.4-dien-3one by Curvularia lunata after 30-44 h. 
Table 3: Effect of the bioconversion time course on the transformation of cortexolone using entrapped spores of $C$. elegans

\begin{tabular}{|c|c|c|c|c|c|}
\hline \multirow{2}{*}{$\begin{array}{l}\text { Bioconversion } \\
\text { time course (h) }\end{array}$} & \multicolumn{5}{|c|}{ Transformation mixture (mg/50mL medium) } \\
\hline & Cortisol & Prednisolone & $\begin{array}{c}\text { 20ß-hydroxy } \\
\text { cortisol }\end{array}$ & $\begin{array}{c}\text { Residual } \\
\text { cortexolone }\end{array}$ & $\begin{array}{c}\text { Transformation } \\
\text { efficiency (\%) }\end{array}$ \\
\hline 12 & 1.1 & 1.0 & 0.5 & 1.9 & 43 \\
\hline 24 & 1.5 & 1.4 & 0.6 & 1.2 & 57 \\
\hline 48 & 2.1 & 1.9 & 0.8 & 0.2 & 80 \\
\hline 72 & 2.2 & 2 & 0.3 & 0.4 & 84 \\
\hline 96 & 1.5 & 1.4 & 0.2 & 1.4 & 58 \\
\hline
\end{tabular}

- Substrate concentration $=5 \mathrm{mg} / 50 \mathrm{~mL}$ medium

- Sodium alginate concentration $3 \%$.

- Spore concentration $=2 \times 10^{7}$ spores $/ \mathrm{mL}$

Table 4: Bioconversion of cortexolone using C.elegans spores adsorbed on different weights of glass wool

\begin{tabular}{cccccc}
\hline $\begin{array}{c}\text { Weight of glass } \\
\text { wool } \mathbf{( g )}\end{array}$ & Cortisol & Prednisolone & 20ß-hydroxy cortisol & $\begin{array}{c}\text { Residual } \\
\text { cortexolone }\end{array}$ & $\begin{array}{c}\text { Transformation } \\
\text { efficiency (\%) }\end{array}$ \\
\cline { 2 - 6 } & 0.9 & 0.8 & 0.7 & 2.2 & 35 \\
0.2 & 1.5 & 1.4 & 0.9 & 0.9 & 59 \\
0.4 & 1.7 & 1.5 & 1.0 & 0.5 & 66 \\
0.6 & 1.8 & 1.7 & 0.8 & 0.3 & 60 \\
1 & 1.7 & 1.6 & 0.8 & 0.9 & 59 \\
Control $^{*}$ & 1.5 & 1.4 & 0.9 & & 56 \\
\hline
\end{tabular}

- Control $^{*}=$ free spores

- Concentration of substrate $5 \mathrm{mg} / 50 \mathrm{~mL}$ medium

- Spores concentration $=2 \times 10^{7}$ spores $/ \mathrm{mL}$

Reutilization of the entrapped $C$. elegans spores in alginate beeds for the biotransformation of cortexolone to cortisol and prednisolone

The immobilized $C$. elegans spores in alginate beads were reused in the biotransformation of cortexolone to cortisol and prednisolone. Figure 1 indicates that the immobilized spores can be reused for 6 runs with the optimum activity at the second cycle. The transformation capacity proved to decrease with the increase of cycle number, and it was also noticed that alginate beads almost dissolved at the sixth run (18 days). The decrease in the beads stability and high leakage of cells during the successive cycles may explain the gradual decrease of the products in the repeated batch cycles. The destabilization of the alginate beads had also been reported by Fraser and Bickerstaff (1997).

\section{Effect of different concentrations of glass wool on the bioconversion of cortexolone}

In the adsorption technique, different weights of glass wool $(0.2,0.4,0.6,0.8, \mathrm{Lg} / 50 \mathrm{~mL})$ were used to adsorb $C$. elegans spores $\left(2 \times 10^{7} / \mathrm{mL}\right)$. The good conversion yields, in favour of cortisol and prednisolone formation were recorded with fungal spores immobilized on $0.8 \mathrm{~g}$ glass wool (Table 4). The amount of the products was relatively higher as compared with free spores. The adsorption process involves three stages: reversible adhesion, irreversible adhesion and micro-colony formation (Marshall et al., 1971). Increasing the glass wool weight more than $1.6 \%(\mathrm{w} / \mathrm{v})$ was accompanied by a decrease in the products due to the less availability of the fungus spores to the transformation medium. Amin (2005) found that the optimum weight of the glass wool used for the biotransformation of glycyrrhizin was $1.2 \%(\mathrm{w} / \mathrm{v})$.

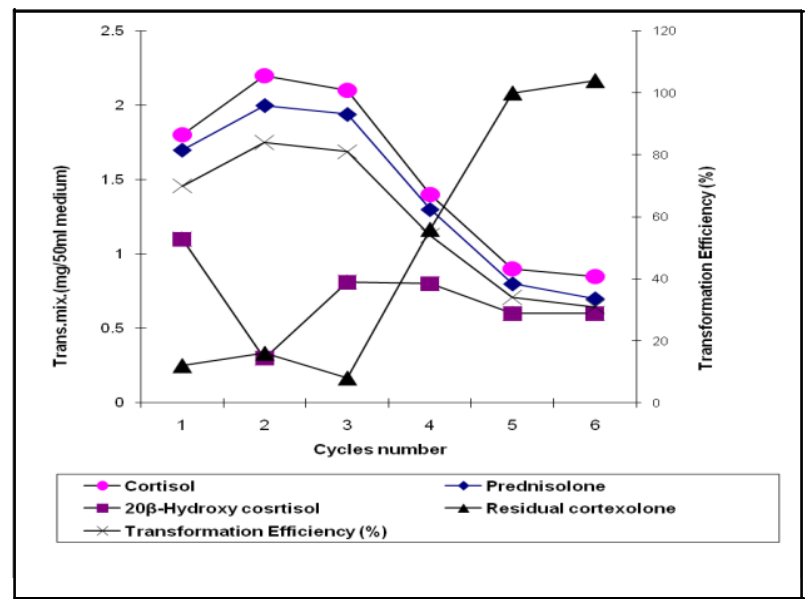

Figure 1: Reutilization of the entrapped spored of $C$. elegans for the biotransformation of cortexolen to cortisol and prednisolone 
Table 5: Biotransformation of cortexolone as influenced by the loaded inoculum size of C.elegans spores on glass wool carrier

\begin{tabular}{cccccc}
\hline $\begin{array}{c}\text { Inoculum size } \\
(\mathbf{m L})\end{array}$ & Cortisol & Prednisolone & $\begin{array}{c}\text { 203-hydroxy } \\
\text { cortisol }\end{array}$ & $\begin{array}{c}\text { Residual } \\
\text { cortexolone }\end{array}$ & $\begin{array}{c}\text { Transformation } \\
\text { efficiency (\%) }\end{array}$ \\
\cline { 2 - 6 } & 1.1 & 1 & 0.5 & 2.1 & 42 \\
10 & 1.8 & 1.7 & 0.3 & 0.9 & 70 \\
15 & 2.1 & 2 & 0.3 & 0.4 & 82 \\
20 & 2.1 & 1.9 & 1.0 & 0.4 & 80 \\
25 & 1.7 & 1.6 & 0.8 & 0.6 & 66 \\
\hline
\end{tabular}

$-1 \mathrm{~mL}=2 \times 10^{\prime}$ spores

- Cortexolone concentration $=5 \mathrm{mg} / 50 \mathrm{~mL}$ medium

- Glass wool wt. $=1.6 \%(\mathrm{wt} / \mathrm{v})$

Table 6: Effect of the bioconversion time course on transformation of cortexolone using adsorbed spores C.elegans on glass wool

\begin{tabular}{cccccc}
\hline $\begin{array}{c}\text { Bioconversion } \\
\text { time course }(\mathbf{h})\end{array}$ & Cortisol & Prednisolone & $\begin{array}{c}\text { 20 } \beta \text {-hydroxy } \\
\text { cortisol }\end{array}$ & $\begin{array}{c}\text { Residual } \\
\text { substrate }\end{array}$ & $\begin{array}{c}\text { Transformation } \\
\text { efficiency (\%) }\end{array}$ \\
\cline { 2 - 6 } & 1.1 & 0.9 & 0.3 & 2.3 & 42 \\
24 & 1.2 & 1.1 & 0.7 & 1.7 & 46 \\
48 & 2.1 & 1.9 & 0.9 & 0.1 & 81 \\
72 & 2.4 & 2.2 & 0.2 & 0.01 & 92 \\
96 & 2.3 & 2.16 & 0.4 & 0.13 & 89 \\
\hline
\end{tabular}

- Cortexolone concentration $=5 \mathrm{mg} / 50 \mathrm{~mL}$ medium

- Glass wool = $1.6 \%(\mathrm{wt} / \mathrm{v})$

- Spores concentration $=2 \times 10^{7}$ spores $/ \mathrm{mL}$

\section{Effect of inoculum size of C.elegans adsorbed on glass wool on the bioconversion of cortexolone}

As it can be seen from Table 5 , the volume of fungus spores loaded on glass wool affected the bioconversion activity. The maximum efficiency (82\%) and the higher productivity of both cortisol and prednisolone were obtained with spore load of $15 \mathrm{~mL}\left(2 \times 10^{7}\right.$ spores $\left./ \mathrm{mL}\right)$. It was noted that the optimal spores loaded on glass wool was similar to that entrapped in alginate beads $(15 \mathrm{~mL}$ i.e. $2 \times 10^{7}$ spores $/ \mathrm{mL}$ ). By further increasing the concentration of the loaded spores the bioconversion process was retarded. Sonomoto et al. (1981) stated that the optimum cell concentration was $1.8 \times 10^{6}$ using $C$. lunata in order to attain good bioconversion yields.

Effect of transformation period on the bioconversion of cortexolone using $C$. elegans spores adsorbed on glass wool

To illustrate the rate of cortexolone transformation using immobilized $C$. elegans spores on glass wool, the products were measured in the fermentation mixtures at different time periods (12, 24, 48, 72 and $96 \mathrm{~h})$. It is clearly evident from Table 6 that the bioconversion efficiencies of cortexolone linearly increased with the increase of transformation period. Evidence has been given that the maximum total production values (92\%) were obtained after $72 \mathrm{~h}$. Increasing the biotransformation period more than $72 \mathrm{~h}$ was accompanied by decreasing the bioconversion activity. It seems that the loaded spores need a definite time to grow and consequently producing the desired enzymes for the bioconversion process. Recently, Amin (2005) found that $96 \mathrm{~h}$ was the optimum incubation period to give maximum production of glycyrrhetic acid from glycyrrhizin using glass wool immobilized $A$. niger spores. Similarly, Manosroi et al. (1999) could obtain prednisolone from transformed cortexolone by mixed cultures of free $C$. echinulata ATCC 8688a with immobilized B. sphaericus ATCC 13805 after $96 \mathrm{~h}$.

\section{Reutilization of the adsorbed $C$. elegans spores on glass wool for the biotransformation of cortexolone to cortisol and prednisolone}

On using the adsorbed fungal spores for cortexolone bioconversion for several batch cycles (Figure 2), the transformation efficiency reached about $94 \%$, with highest productivity for hydrocortisone and prednisolone at the end of the second batch. These yields were of higher magnitude than that obtained by the free cells. However, the bioconversion estimates decreased gradually up to the 5 th run. Obviously, reutilization of fungal spores adsorbed on glass wool appeared to be the most successful treatment wherein they maintained about $50 \%$ of their 


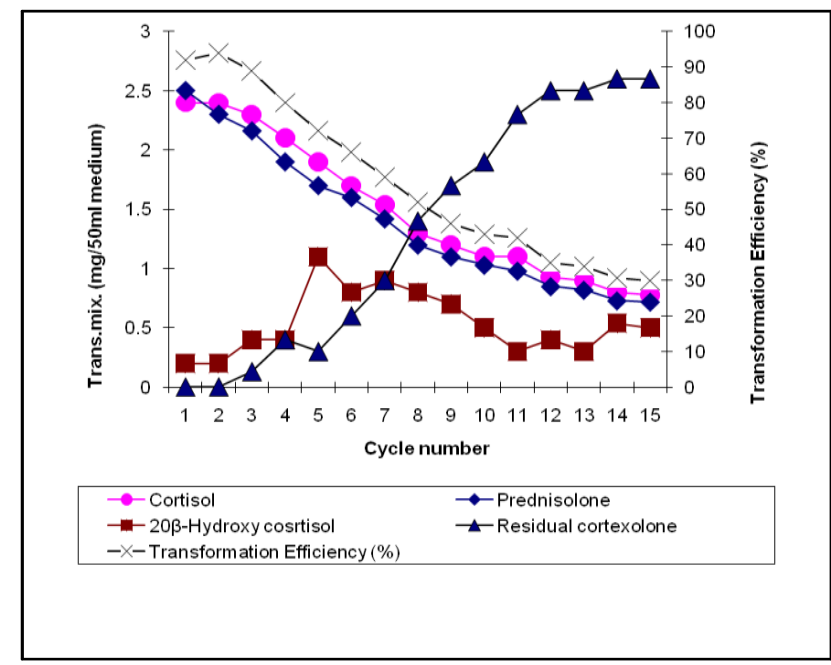

Figure 2: Reutilization of the adsorbed C. elegans spores on glass wool for the biotransformation of cortexolone to cortisol and prednisolone

productivity during 24 days, including 8 successive cycles. Moreover the adsorbed fungal spores still exhibited bioconversion activities (although of lower magnitudes) as the recyclization process was extended for further repeated 8 cycles. Similarly Wang et al. (1998) stated that cells can be used for six runs without any significant decrease in activity. However, from the seventh run the hydrocortisone yield began to decrease.

\section{CONCLUSIONS}

From this study, we can conclude that the transformation of cortexolone to cortisol and prednisolone using adsorbed $C$. elegans spores on glass wool was higher than that using the entrapment in calcium alginate gel technique. The optimum condition to obtain maximum transformation of cortexolone was $72 \mathrm{~h}$ using $2 \times 10^{7}$ spores $/ \mathrm{mL}$. The total amount of hydrocortisone and prednisolone formed during the repeated use of $C$. elegans spores entrapped in alginate beads were $9.25 \mathrm{mg}$ and $8.44 \mathrm{mg}$ respectively from $30 \mathrm{mg}$ cortexolone (operational period, 18 days).

On the other hand, the total amount of hydrocortisone formed was $22.45 \mathrm{mg}$ and prednisolone was $20.71 \mathrm{mg}$ from $75 \mathrm{mg}$ cortexolone (operational period 45 days) in the adsorption technique. Such immobilization method might be important from a practical view point for the production of useful compounds.

\section{REFERENCES}

Amin, H. A. S. (2005). Studies on the bioconversion of glycyrrhizin. Ph.D Thesis. Faculty of Science, Botany Department, Cairo University.

Asha, S. and Vidyavathi, M. (2009). Cunninghamella - A microbial model for drug metabolism studies - A review. Biotechnology Advances 27, 16-29.
Bickerstaff, G. F. (1997). Immobilization of enzymes and cells. In: Immobilization of enzymes and cells: Methods in Biotechnology. Bickerstaff, G. F. (ed.). Humana Press, Inc., Totowa, New Jersey. 1-11.

Chinckolkar, S. B., Laxman, R. S. and Wakharkar, R. D. (1995). Hydroxylation of progesterone by $C$. blakesleeana NCIM 687. World Journal of Microbiology and Biotechnology 11(3), 357-358.

Dias, A. C. P., Cabral, J. M. S. and Pinheiro, H. M. (1994). Sterol side-chain cleavage with immobilized Mycobacterium cells in water immiscible organic solvents. Enzyme Microbial Technology 16, 708-714.

Dlugonski. J, Paraszkiewicz, K. and Sedlaczek, L. (1997). Maintenance of steroid 11-hydroxylation activity in immobilized Cunninghamella elegans protoplasts. World Journal of Microbiology and

Biotechnology 13, 469-473.

Farid, M. A., El-Diwany, A. I. and El-Enshasy, H. A. (1994). Production of oxytetracycline and rifamycin Band SV with cells immobilized on glass wool. Acta Biotechnologica 14, 67-74.

Fernandes, P., Cruz, A., Angelova, B., Pinheiro, H. M, and Cabral J. M. S. (2003). Microbial conversion of steroid compounds: Recent development. Enzyme Microbial Technology 32, 688-705.

Fraser, J. F. and Bickerstaff, G. F. (1997). Entrapment in calcium alginate. In: Immobilization of enzymes and cells: Methods in Biotechnology. Bickerstaff, G. F. (ed.). Humana Press Inc., Totowa, New Jersey. 6166.

Fukui, S., Sonomoto, K., Itoh, N and Tanaka, A. (1980). Several novel method for immobilization of enzymes, microbial cells and organelles. Biochimie 62, 381386.

Houng, J. Y., Chiang, W. P. and Chen, K. C. (1994). $11 \alpha$-Hydroxylation of progesterone in biphasic media using alginate entrapped Aspergillus ochraceus gel beads coated with polyurea. Enzyme Microbiology and Technology 16, 485-491.

Koshcheyenko, K. A., Turkina, M. V. and Skryabin, G. K. (1983). Immobilization of living microbial cells and their application for steroid transformation. Enzyme and Microbial Technology 5, 14-21.

Lu, W. Y, Du, L. X., Wang, M., Wen, J. P., Sun, B. and Guo, Y. W. (2006). Effect of two-steps substrate addition on steroids $11 \beta$ - hydroxylation by Curvularia lunata CL-114. Biochemical Bioengineering Journal 32, 233-238.

Lu, W., Du, L., Wang, M., Jia, X., Wen, J., Huang, Y., Guo, Y., Gong, W., Bao, H., Yang, J. and Sun, B. (2007). Optimization of hydrocortisone production by Curvularia lunata. Applied Biochemistry and Biotechnology 142, 17-28.

Lusta, K. A., Starostina, N. G., Gorkina, N. B., Fikhe, B. A., Lozinskii, V. L., Vainermon, E. S. and Rogoezhin, S. V. (1989). Immobilization of E. coli in macroporous cryogels on polyacrylamide. Biotechnology and Bioengineering 24(2), 418-426. 
Mahato, S. B. and Garai, S. (1997). Advances in microbial steroid biotransformation. Steroids 62, 332345.

Manosroi, J., Saowakhon, S. and Manosroi, A. ( 2007). A novel one-step biotransformation of cortexone - 21 -acetate to hydrocortisone acetate using Cunnighamella blakesleeana ATCC 8688a. Enzyme and Microbial Technology 41, 332-325.

Manosroi, J., Chisti, Y. and Manosroi A. (2006). Biotransformation of cortexolone to hydrocortisone by molds using rapid color- development assay. Applied Biochemistry and Microbiology 42(5), 479-483.

Manosroi, J., Abe, M. and Manosroi, A. (1999). Biotransformation of steroidal drugs using microorganisms screened from various sites in Chiang Mai, Thailand. Bioresource Technology 69(1), 67-63.

Marshall, K. C., Stout, R. and Mitchell, R. (1971). Mechanism of the initial events in the sorption of marine bacteria to surfaces. Journal of General Microbiology 68, 337-348.

Martine, C. K. A. (1984). Cited from Biotechnology. Vol. 61. Rehm, H. J. and Reed, G. (eds.). Chap. 3. 79-95.

Naim, N., Adham, N. Z., Abd El-Rhim, R. and Abd-ElHady, A. (2003). Prednisolone production using Pseudomonas fluorescens cells immobilized with polymer carrier produced by radiation polymerization. Process Biochemistry 38, 1083-1089.

Paraszkiewicz, K. and Dlugonski, J. (1998). Cortexolone $11 \beta$-hydroxylation in protoplasts of Curvularia lunata. Journal of Biotechnology 65, 217224.

Peterson, D. H. and Murray, H. C. (1952). Microbiological oxygenation of steroid at carbon 11. Journal of American Chemical Society 74, 1871-1872.

Schmauder, H. P., Schlosser, D., Gunther, T., Hattenbach, A., Sauerstein, J., Jungnickel, F. and Augsten R. (1991). Application of immobilized cells for steroid transformation. Journal of Basic Microbiology 7, 187-236.

Sonomoto, K., Hoq, M. M. D., Tanaka, A. and Fukui, S. (1983). 11 $\beta$-Hydroxylation of cortexolone (Reichstein's compound $S$ ) to hydro cortisone by Curvularia lunata entrapped in photo-cross-linked resin gels. Applied Environmental Microbiology 45, 436-443.

Sonomoto, K., Hoq. M. M. D., Tanaka, A. and Fukui, S. (1981). Growth of Curvularia lunata spores into mycelial form with various gels, and steroid $11 \beta$ hydroxy1ation by the entrapped mycelia. Journal of Fermentation Technology 59(6), 465-469.

Sripalakit, P., Wichai, U. and Sara Phanchotiwitthaya, A. (2006). Biotransformation of various natural sterols to androstenones by Mycobacterium sp. and some steroid-converting microbial strains Journal of Molecular Catalysis B: Enzymatic 41, 49-54.

Suzuki, K., Sabga, K., Chikaoka, Y. and Itagaki, E. (1993). Purification and properties of cytochrome $P$ 450 catalyzing steroid $11 \beta$-hydroxylation in Curvularia lunata. Biochimika Biophysika Acta 1203, 215-223.
Wang, J., Chen, C., Li, B., Zhang, J. and Yu, Y. (1998). Production of hydrocortisone from cortexolone-21acetate by immobilized Absidia orchidis in cosolvent containing media. Enzyme Microbial Technology 22, 368-373.

Yang, J., Yang, S., Yang. Y., Zheng, H. and Weng, L. (2007). Microbial hydroxylation of $16 \alpha, 17 \alpha$-dimethyl$17 \beta$-(I-oxopropyl) androsta-I,4-dien-3-one to rimexolone by Curvularia lunata AS 3.4381. Journal of Molecular Catalysis B: Enzymatic 47, 155-158. 